evidence of CMV infection at post-mortem, eight were receiving steroid therapy (Evans and Williams, 1968). The benefit of steroid therapy in the GuillainBarré syndrome has yet to be proved (Leading Article, 1975) and, in view of the fatal outcome of the present case, should perhaps be avoided in cases due to CMV infection. Since virological proof of CMV infection only becomes available at a late stage of a patient's illness, earlier evidence should be sought, such as the presence of abnormal liver function tests and abnormal mononuclear cells in the peripheral blood, with a negative Paul Bunnell test.

\section{Acknowledgment}

We thank Dr M. H. Oelbaum for permission to report this case.

\section{References}

BALL, S.G. \& ARCHer, G.J. (1976) Myocarditis complicating cytomegalovirus mononucleosis. Postgraduate Medical Journal, 52, 102.

LeAding Article (1975) Guillain-Barré syndrome. British Medical Journal, 3, 190.

Chawla, H.B., Ford, M.J., Munro, J.F., Scorgie, R.E. \& WATSON, A.R. (1976) Ocular involvement in cytomegalo- virus infection in a previously healthy adult. Brit鬼h Medical Journal, 2, 281.

Evans, D.J. \& Williams, E.D. (1968) Cytomegalic inclusiọn disease in the adult. Journal of Clinical Pathology, 21, 3 .

Jordan, M.C., Rousseau, W.E., Stewart, J.A., NobIE, G.R. \& CHIN, T.D.Y. (1973) Spontaneous cytomegalovims mononucleosis. Annals of Internal Medicine, 79, 153.

Klemola, E. \& KaARianinen, L. (1965) Cytomegalovifis as a possible cause of a disease resembling infectiopis mononucleosis. British Medical Journal, 2, 1099.

Klemola, E., KaAriainen, L., von Essen, R., Haltia, fu., KoIvuniemi, A. \& von BonsdorfF, C.-H. (1967a) Further studies on cytomegalovirus mononucleosis in previouspy healthy individuals. Acta medica scandinavica, 182, $311 \overrightarrow{\overrightarrow{.}}$

Klemola, E., Weckman, N., Haltia, K. \& KaARiainen, $\vec{D}$. (1967b) The Guillain-Barré syndrome associated wigh acquired cytomegalovirus infection. Acta medica scan inavica, 181, 603.

K RECH, U., JUNG, M. \& JUNG, F. (1971) In: Cytomegalovitys Infections of Man. Karger, Basle.

LAMB, S.G. \& STERN, H. (1966) Cytomegalovirus mo nucleosis with jaundice as presenting sign. Lancet, ii, 1000.

LeONARD, J.C. \& ToBIN, J.O'H. (1971) Polyneuritis associated with cytomegalovirus infections. Quarterly Journal $\overrightarrow{\text { Nof }}$ Medicine, 159, 435.

STERN, H. \& ELEK, S.D. (1965) The incidence of infect於 with cytomegalovirus in a normal population. Journal of Hygiene, 63, 79.

Tobin, J. O'H., MacDonald, H., Doyce, L. \& TAYloR, J星.

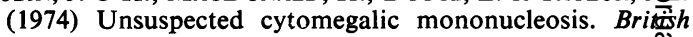
Medical Journal, 2, 385.

\title{
Phenobarbital dyskinesia
}

\author{
S. L. LIGHTMAN \\ M.A., M.R.C.P. \\ Middlesex Hospital, London W1N $8 A A$
}

\begin{abstract}
Summary
A patient was admitted to hospital following an overdose of phenobarbital. During her recovery she developed both chorea and torsion dystonia which could only be related to her high plasma phenobarbital levels.
\end{abstract}

DiphenYLhydantoin (phenytoin) overdose is a well recorded cause of chorea and dystonia. A case is now reported of a patient who showed these features after phenobarbital alone. This is thought to be the first report of such an occurrence.

\section{Case report}

A 36-year-old nurse was brought by ambulance to the casualty department, having been found semicomatose at a reception centre in central London. She was known to have a personality disorder and was on treatment with diazepam $15 \mathrm{mg} /$ day aqud dichloralphenazone $1300 \mathrm{mg}$ at night, prescribed $0 \mathrm{n}$ a daily basis to obviate the danger of overdosage?

On admission she responded in a co-ordinated fashion to painful stimuli but was unresponsive go verbal commands. Her cardiovascular, respiratory and abdominal systems were unremarkable, and ${ }_{\text {n }}$ her central nervous system no focal abnormalitîj,s could be detected. Her pupils were equal and reacfed well to light, she had no doll's eye movements and tostr fundi were clear. Her reflexes were all present atojd equal and her plantars flexor.

The following day she was still very drowsy axid only arousable by painful stimuli, and it was ofy 36 hours after admission that she woke up. At this time she was alert and orientated, and while lying in bed she was seen to have choreic movements ab\%it the eyes and mouth, and torsion movements at 
shoulder with intorsion of the upper limbs. She also showed athetoid movements of the toes. In addition to these spontaneous movements, examination revealed a dysarthria, phasic nystagmus (more marked to the left owing to an unwillingness to look to the right) and a severe gait ataxia.

The abnormal spontaneous movements gradually decreased over the next 24 hours, and by 72 hours after admission had completely vanished. At this time her nystagmus had also stopped, although her ataxia had now changed in type and was closely related to being observed.

A drug screen was taken at the time of admission and this showed a plasma concentration of $88 \mathrm{mg} /$ litre of phenobarbital (comatose level usually being greater than $75 \mathrm{mg} /$ litre), there was no phenytoin detected, and only a trace of diazepam. On questioning the patient later she admitted that she had stolen the phenobarbital from a friend who was epileptic, and that the only diazepam she had taken was her normal dose $(15 \mathrm{mg} /$ day $)$ that she had been taking for several months.

\section{Discussion}

It seems unequivocal in this patient that the chorea and torsion dystonia noted in the recovery phase from her phenobarbital overdose were directly related to toxic levels of this drug. It is of course well recognized that anticonvulsants, when taken in excess, are able to produce a variety of dyskinesias. Chorea and dystonia, however, have only been recorded in patients who have grossly elevated serum levels of phenytoin, and have never been reported with other anticonvulsants alone. A recent review (Chadwick, Reynolds and Marsden, 1976) states categorically that "diphenylhydantoin, but not other anticonvulsants, may cause orofacial dyskinesias, limb chorea and dystonia in intoxicated patients'. The present case demonstrates that both chorea and torsion dystonia may be caused by phenobarbital alone.

\section{Acknowledgments}

I am grateful to Dr J. D. H. Slater for allowing me to report this case, and to Dr M. J. G. Harrison for his help.

\section{References}

Chadwick, D., Reynolds, E.H. \& Marsden, C.D. (1976) Anticonvuisant-induced dyskinesias: a comparison with dyskinesias induced by neuroleptics. Journal of Neurology, Neurosurgery and Psychiatry, 39, 1210.

\section{Cerebral haemorrhage in haemophilia}

\author{
Michael BENNETT* \\ M.B., B.S., M.R.C.P.
}

\author{
JohN A. Sills \\ M.B., B.Chir., M.R.C.P., D.C.H.
}

The Royal Infirmary and Royal Hospital for Sick Children, Edinburgh

\begin{abstract}
Summary
A young male haemophiliac child is here described in whom intracerebral haemorrhage required craniotomy and the subsequent insertion of a ventriculo-peritoneal shunt. These procedures can now be attempted in severe haemophilia $A$ because of the ease in clotting factor replacement therapy.
\end{abstract}

\section{Introduction}

The occurrence of a cerebral haemorrhage in a haemophiliac has nearly always a fatal outcome (Silverstein, 1960). Recently, however, there has been a rapid advance in the treatment of haemophilia

\footnotetext{
* Present address: Department of Haematology, The Royal Free Hospital, London NW3 2QG.
}

with the development of potent small volume human factor VIII replacement therapy. Here, now, is described how such modern therapy was applied to a haemophiliac with cerebral haemorrhage in an attempt to improve the prognosis.

\section{Case report}

The patient was diagnosed as having haemophilia $A$ at the age of nine months. Bruising had been notice during the preceding two months. The biological factor VIII level was $2 \%$, factor IX level was $96 \%$ and the bleeding time (Ivy) was normal at $3 \mathrm{~min}$. The platelet count was $480 \times 10^{9} / 1$ and the prothrombin time was normal. There was no family history of a bleeding diathesis. Over the next three 